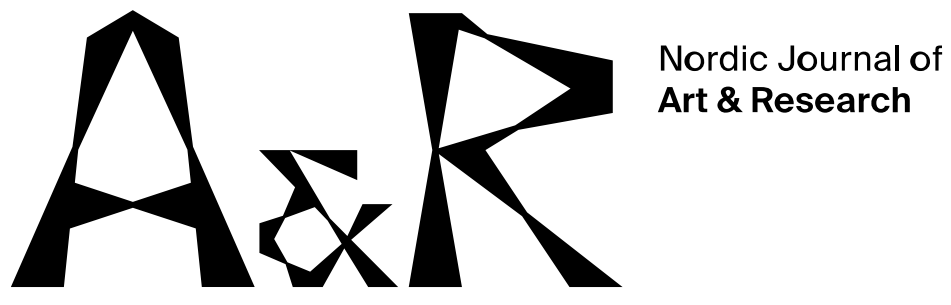

\title{
Researching public art and public space
}

\section{Editorial}

\author{
Olga Schmedling ${ }^{1}$ \\ Oslo National National Academy of the Arts
}

This special issue is devoted to research on the changing paradigms of public art, and of public spaces. Today all art can be characterized as public since it is mediated via relational networks. The shift of paradigm from modernist art to contemporary art coincides with this shift of paradigm - from consumption to communication - in the sense that advanced art practices had already absorbed the change from individual mediation to relational networks. In the communication network of relations, artists and works are constitutive elements. Without the works and the artists, the relational network does not exist, and vice versa: Without the network of relations, neither artists nor works are made visible. This constitutive reciprocity of relations is decisive both for theorists doing research on public art and art in public spaces, as well as for artists who are doing research in public spaces.

Today, more than before, art involves institutions, critics, and audiences. Research on art, as well as research by artists, must take into account not only the artwork itself, but also the process of production, circulation, context, and consumption/reception. Consequently, conventional approaches do not seem to work anymore. As the work of art itself, its basic conditions of existence, and its system of coordinates in space and time are transformed, it seems one may need different descriptions and definitions of art. Such descriptions and definitions must break with 
Olga Schmedling. Researching public art and public space

the usual forms of public and private, space and time, subjectivity and objectivity, in order to address public art as well as research on public art.

By highlighting and questioning these interdependencies, contemporary art research actively participates in shaping our understanding of art, public art, public spaces, and art in public spaces.

As our cover image we have chosen a picture of Marianne Heske's public artwork House of Commons in the square, Eidsvoll plass, in front of the parliament, Stortinget. This square is recognized as a symbolic public site, as one of the country's most important arenas for people's freedom of expression. More than 300 political demonstrations are held here every year. When Heske's House of Commons was placed here it provoked a storm of reactions - which just shows the importance of debating art, public art and public space in public where anyone can participate.

In this first part of a two-pronged special issue on public art and public space, the following five critics, researchers and theorists have contributed.

Line Ulekleiv explores in her essay From Underground to collective platforms how, in the digital age, two artists from different generations in former totalitarian countries, Russian Ilya Kabakov and Czech Kateřina Šedá, investigate ways of surpassing the east-west divide in their collective artistic practices. Ulekleiv also investigates new public spheres and platforms in Albania.

Marion Hohlfeldt, asks in her article Public Art Research in the Open, in what ways public artistic research projects per definition presuppose interdisciplinarity and how collaboration beyond the confinement of various fields may contribute to questioning what is traditionally called knowledge.

In Artistic research in processes of urban change Charlotte Blanche Myrvold focuses on the potential role of artistic research using the urban development of Bjørvika in Oslo as her point of departure. She reflects upon how artistic research expands the roles ascribed to public art in the discourses on the 'creative city' and the 'temporary city'. Myrvold argues that artistic research methodologies challenge stereotypes of publicness and produce alternative ways to 'learn the city' that are necessary expansions to the dominant disciplinary approaches in urban development and planning. 
Olga Schmedling. Researching public art and public space

Mikkel B. Tin discusses in Form, exform, and information how the urban environment can be seen as a text consisting of formal components assembled according to certain syntactic rules. By breaking these rules, or introducing alien components into the urban text, the artist recharges old forms with new and alternative information.

Camilla Eeg-Tverbakk contributes with the article Dramaturgies of reality - shaping and being shaped by things, in which she discusses how public works of art change the dramaturgy of public space through the way things are placed, shaped, and designed in relation to each other. Drawing on object-oriented thinking, she explores three works that invite audiences to experience reality in ways that can open up unknown perspectives and perceptions, through the way the artists organize or reorganize public space and give the selected materials (in this case a wooden house, bricks, and human bodies) agency to act.

This issue has been allocated some support from the Artistic Research Committee (KUF) at Oslo National National Academy of the Arts (KHiO).

\section{About the editor}

Olga Schmedling, Dr. Philos, is professor emerita at Oslo National Academy of the Arts. Schmedling was educated at the University of Oslo and the University of Paris I, Sorbonne, with a doctoral thesis on Changing Paradigms of Art and Architecture in a Social-historical perspective (Schmedling, 2009), after a research fellow-period in the interdisciplinary project Visual Expressions in the Public Realm (VISROM). Schmedling has worked as a critic and an editor in SIKSI Nordic Art Review, and as editor in chief of Norwegian Art Yearbook. She has held positions at the Munch Museum and at Academy of Art and Design, Gothenburg, and was the director of KIK Centre for Contemporary Art and Craft in Oslo, vice-president in the International Association of Art Critics AICA, and president of the national section of AICA. Since 2012, she has been a member of the editorial board of Nordic Journal of Art and Research.

\section{Reference}

Schmedling, O. (2009). Monument og modernitet : endring av kunst og arkitektur $i$ sosialhistorisk perspektiv i de siste to hundre år. Det humanistiske fakultet, Universitetet i Oslo Unipub, Oslo. http://urn.nb.no/URN:NBN:no-33423 